\title{
Endothelial Progenitor Cell Identification, Classification and Nomenclature: A Review
}

\author{
Sandhu $\mathbf{K}^{1 *}$, Njoroge $\mathbf{W}^{2}$, Yang $\mathbf{Y}^{2}$, Harper AGS ${ }^{2}$ and Butler $\mathbf{R}^{1}$ \\ ${ }^{1}$ Department of Interventional Cardiology, Royal Stoke University Hospital, Stoke-on-Trent ST4 6QG, UK \\ ${ }^{2}$ Institute of Science and Technology in Medicine, School of Medicine, Keele University, Stoke-on-Trent ST4 7QB, UK
}

\begin{abstract}
Endothelial integrity depends on a balance between the extent of endothelial cell injury and the capacity for endogenous repair. An imbalance is thought to be a contributory factor for development of atherosclerosis. In healthy individuals mature neighboring endothelial cells may replicate and therefore replace damaged cells. This mechanism has limited potential and therefore an alternative mechanism is also required. One that is proposed mechanism is of undifferentiated cells migrating to sites of vascular injury and then differentiate into mature endothelial cells. These cells are also thought to perpetuate the mechanism by secreting pro-angiogenic cytokines. However, there currently remains a lack of consensus on phenotypic and functional definition of endothelial precursor cells.
\end{abstract}

This review summarizes the current controversies surround the identification, nomenclature and classification of EPCs.

\section{Introduction}

Endothelial integrity depends on a balance between the extent of endothelial cell injury and the capacity for endogenous repair. Loss of endothelial integrity may cause atherosclerosis leading to coronary heart disease and stroke [1-4]. In healthy individuals, neighboring mature endothelial cells are capable to replicate locally and replace damaged cells [1]. However, local replication has limited potential and may be insufficient if the injurious stimuli remains prolonged and or repeated [5]. Therefore an alternative mechanism is required. One proposed mechanism is dependent on undifferentiated cells migrating to sites of vascular injury [6-8] then differentiating into mature endothelial cells [9-16]. These undifferentiated cells are thought to have a central role in vascular repair by their ability to proliferate, migrate to site of vascular injury and then differentiate into mature vascular endothelium $[16,17]$. They are also capable of augmenting this cycle by secreting pro-angiogenic cytokines [18-20]. Intense research has followed since the first reported observation of a bone marrow derived circulating progenitor cells termed endothelial progenitor cell (EPC) by Asahara et al. [21,22] EPCs are thought to be derived from pluripotential stem cells within the bone marrow and accounting for only $0.001-0.0001 \%$ of peripheral blood cells [23]. Circulating EPCs are then thought to migrate to areas of vascular damage and differentiate into mature endothelial cells [21]. EPCs can be isolated from bone marrow or the circulation as a sub population of mononuclear cells $[21,24,25]$ expressing a variety of endothelial surface markers [26].

However, there currently remains a lack of consensus EPC identification and function [27-32]. This may be confounding this, some studies have utilized EPC samples made of heterogenous cell population without recognition of the possible synergistic effect of different cell populations [33]. Furthermore EPCs are often referred to as a diverse group of cells lineages having angiogenic potential despite some of these cell populations being unable to differentiate into functional endothelial cells [27]. Consequently the current EPC nomenclature proposed over a decade ago is widely regarded as suboptimal [34]. This has made it difficult to clarify the role of EPCs in health and disease [35].

The review below highlights current controversies on a general consensus on a working definition on identification of EPCs [31]. The review will approach the current controversies on identification and function of EPCs by considering limitations of the commonly used laboratory methods used in EPC identification.

\section{Clinical applications}

EPC are currently not measured routinely in clinical practice but understanding the role and EPCs in both health and disease are a focus of recent research. They remain very much a research tool at present. However it is now generally accepted that cardiovascular risk correlates with EPC number, highlighting the integral relationship between endothelial integrity and atherosclerosis [36-40]. With impaired EPC function being associated with cardiovascular events in several studies [6,38-40]. Decreased numbers have been found in patients with traditional risk factors for coronary artery disease including smoking, hypertension, [41] diabetes mellitus, [42-47] elevated lowdensity lipoprotein cholesterol $[48,49]$ and hypercholesterolemia [4853]. Disruption of endothelial integrity by endothelial cell injury has been shown to be a stimulus for the development of atherosclerosis [4] as well as augmentation of EPC number and function [12,54,55]. Continued endothelial damage [56] may eventually lead to a reduction of the number of EPCs resulting in deficient endothelial repair and progression of atherosclerosis and increased risk of myocardial ischaemia [12,48]. This has led to research examining the effect of EPC being infused in patients with intractable angina, post myocardial infarction left ventricular recovery and in chronic heart failure patients with some studies showing beneficial outcomes [57-66]. The REPAIRAMI trial found at 12 months the end points were significantly reduced in the bone marrow-derived progenitor cells group compared with placebo but also that the bone marrow-derived progenitor cells were independent predictor of favorable clinical outcome [67].

*Corresponding author: Sandhu $\mathrm{K}$, Department of Interventional Cardiology, Royal Stoke University Hospital, Stoke-on-Trent ST4 6QG, UK, Tel: +44-1782 675953; E-mail: ksandhu@hotmail.com

Received June 20, 2018; Accepted June 25, 2018; Published June 30, 2018

Citation: Sandhu K, Njoroge W, Yang Y, Harper AGS, Butler R (2018) Endothelial Progenitor Cell Identification, Classification and Nomenclature: A Review. J Blood Lymph 8: 221. doi:10.4172/2165-7831.1000221

Copyright: ( 2018 Sandhu K, et al. This is an open-access article distributed unde the terms of the Creative Commons Attribution License, which permits unrestricted use, distribution, and reproduction in any medium, provided the original author and source are credited. 


\section{The identification and classification of endothelial progenitor cells (EPCs)}

There are currently two laboratory methods commonly used for identification and classification of EPCs'. The first a blood based assays quantified by a number of specific cell surface markers using flow cytometry. The second by the number of colonies of adherent cells that can be obtained from circulating mononuclear cells (MNCs) expressing mature endothelial cell markers in-vitro by cell culture isolation [68].

\section{Flow cytometric analysis}

Flow cytometry can be used to identify and quantify the density of cells of interest through fluorimetric analysis of specific cell surface markers. There remains controversy regarding which specific markers identify EPCs. EPCs, thought to be derived from CD34 hematopoietic progenitor cells, $[9,21,24,26]$ with co-expression of specific endothelial marker proteins $[9,24,26]$. With certain cell surface markers thought to be related to the stage of maturations of the EPC, such as, the cell surface marker CD133, a $120-\mathrm{kDa}$ trans-membrane polypeptide. CD133 found to be expressed on bone marrow derived hematopoietic stem and progenitor cells in peripheral blood [69]. Interestingly expression of CD133 decreases to a complete absence in mature EPCs within the peripheral circulation. The timing of the loss of expression of CD133 from EPCs remains unclear [70]. However, the loss of CD133 indicates the transformation to more mature endothelial like cells [69]. The converse is true for the expression of CD34 a cell surface marker found on immature pluri-potential stem cells [26]. CD34 gradually increases as the CD133 decreases as the EPC matures [69]. The value of using CD133 as a marker of EPC remains contentious firstly due to the rarity of cells expressing CD133 and more importantly studies suggest that CD133 are haematopoietic cell lines and therefore unable to form endothelial phenotypic EPCs [71,72].

Certain authors suggest a minimal antigenic profile should include at least 1 marker of immature cells, commonly CD34 and/or CD133 plus at least 1 marker of endothelial cells commonly VEGFR2 (KDR/ Flk-1). CD133 either alone or in combination with CD34/VEGFR2 have been used for identification of EPCs in some studies $[26,73]$. Whereas as other studies suggest expression of CD34, CD133, and/ or VEGF2 [23,27,71,74,75]. Table 1 summarizes and compares the distinct expression of three commonly used markers within bone marrow and EPCs. Some authors propose EPCs being derived from CD45-lineage [23]. Interestingly CD34, VEGFR2 and diminished CD45 (CD45dim) cells have been found to have greater correlation to coronary heart disease and response to statins when compared to healthy individuals [76,77]. With the combination of CD133, CD34 and VEGFR-2 associated with early functional EPCs [10,26].

Therefore EPCs may express markers of both hematopoietic stem cells (CD34 and CD133) and endothelial cells (CD146, vWF, and VEGFR2) [23,24,26,69,72,78-82] amongst other proposed markers $[21,69,70,83]$. Hence current flow cytometric identification of EPCs remains controversial.

\begin{tabular}{|l|c|c|c|}
\hline & Bone marrow & \multicolumn{2}{|c|}{ Circulation } \\
\hline & & Early EPCs & Mature EPCs \\
\hline CD133 $^{+}$ & + & $+/-$ & - \\
\hline CD34 $^{+}$ & + & + & + \\
\hline VEGFR2 $^{+}$ & + & ++ & +++ \\
\hline
\end{tabular}

Table 1: Cell surface markers during course of maturation of EPCs (Adapted from Sandhu et al.) [32].

\section{Cell culture analysis}

Cell culture allows identification by formation of colonies of cells that have a pattern of immunofluorescence identifying functioning endothelial cell lines [84]. Asahara et al first isolated and defined EPCs as circulating mononuclear cells expressing CD34 and Flk-1 with further cell culture identification by CD31, uptake of acetylated LDL, and lectin binding [21]. Characteristics that are still commonly used to define EPC in cell culture.

Cell culture definitions of EPCs also lack phenotypic specificity for a number of reasons. Firstly, micro-particles from platelets may transfer CD31 to haematopoietic cells [85]. Secondly CD31 and vascular endothelial growth factor receptor 2 (VEGFR2) may also be found in some monocytic subpopulations [86]. Finally AcLDL uptake and lectin binding have been found in both macrophages and mature endothelial cells [29].

A number of studies have described two types of time-dependent cell colonies with distinct properties. The spindle shaped early outgrowth EPC (EO-EPC) seen in the early period of culture and late outgrowth EPC (LO-EPC) that produce colonies and tube formation in latter period of culture $[12,21,33,87-90]$. These two populations have very different phenotypes, EO-EPC is thought of as haematopoietic and LO-EPC as endothelial cell lines [91]. This has led to populations being named as "hematopoietic EPCs" and "non-hematopoietic EPCs" [92]. Thereby supporting the hypothesis of hematopoietic EPCs giving rise to non-hematopoietic EPCs and ultimately endothelial cells.

Early outgrowth EPC (EO-EPC) are thought to be short-lived cells $(<2$ weeks) and do not differentiate into endothelial cells in vivo but have the ability to restore endothelial function and enhance angiogenesis after tissue ischaemia through a paracrine mechanism $[21,80,93]$. However, they are thought to be a heterogeneous population of hematopoietic cells [93-95] and often referred to as circulating angiogenic cells (CACs) [96]. CACs have been produced in-vitro in cell culture conditions, however there is little evidence to suggest that this occurs in-vivo. Leading to some authors to suggesting that this cell population be termed as myeloid angiogenic cells (MACs) based on their lineage and function [29]. MACs are characterized by cell culture immune-phenotyping with CD45, CD14, CD31, and negative for CD146, CD133, and Tie2 [97,98]. These cells have potent pro-angiogenic and vaso-reparative effect by a paracrine mechanism [15,99-101]. Importantly, they are not capable of becoming endothelial or progenitor cells $[31,102]$. Therefore the terms MACs/CACs should not be used interchangeably with EPCs [29].

In contrast LO-EPCs, are thought to be homogeneous endotheliallike progenitor cell population that possess a high proliferative potential, differentiate into vascular endothelial cells and form networks in vitro and in vivo. Furthermore LO-EPCs are also capable of augmenting the process by auto paracrine mechanism [29,33,103-106]. A mechanism noted in patients with cardiovascular risk factors [104,107]. New recommendations have suggested that this population of cells perhaps should be referred to as endothelial colony forming cells (ECFCs) $[25,29]$. ECFCs derived from peripheral blood mononuclear cells, or umbilical cord blood grown in endothelial cell culture conditions are characterized by immunophenotype positive for CD31, VE-Cadherin, von Willebrand factor, CD146, VEGFR2, and negative for CD45 and CD14. CD34 expression may also be expressed however may decline during in-vitro expansion $[103,108,109]$ as mentioned above under flow cytometric analysis.

Interestingly, the proliferative, differentiation and tube forming 


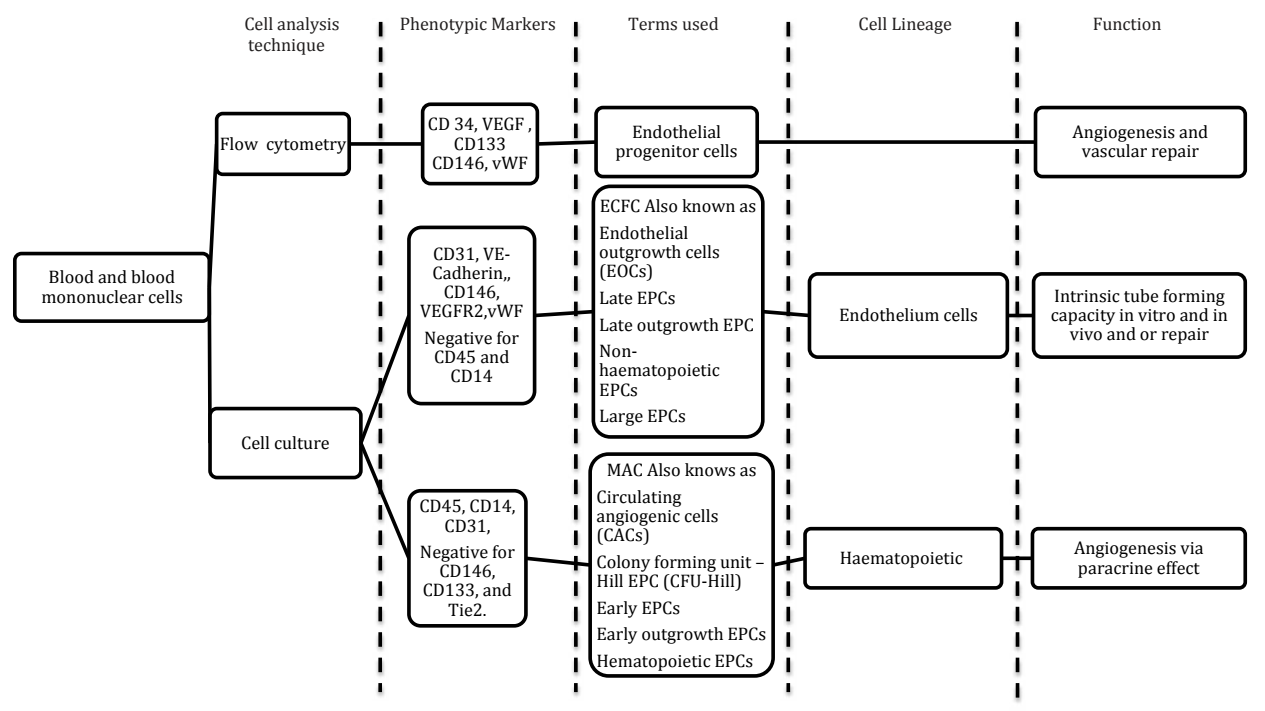

Abbreviations: EPC: Endothelial Progenitor Cell; ECFC: Endothelial Colony Forming Cells; MAC : Myeloid Angiogenic Cells; vWF : von Willebrand Factor. Figure 1: Table summarising cellular analysis technique, phenotype markers, preferred nomenclature and function of cells often termed as EPC in current literature.

ability have been found to been enhanced by laminar shear stress [110113] suggesting that they may contribute to autologous vascular repair. This is an important finding raising the possibility of using these cells as viable treatment option for cardiovascular patients [90]. However any future use in as a treatment option would require an ex-vivo production due to the low concentrations of LO-EPC in-vivo $[87,114]$.

The use of ECFCs and MACs are preferentially used terms as this definition accurately describes the phenotype and function of these cell-types [102,115]. Figure 1 adapted from Medina et al. [29] summarizes cellular analysis technique, phenotype markers, preferred nomenclature and function of cells often termed as EPC in current literature.

\section{Conclusion}

Since the first reported reports of bone marrow derived circulating cells differentiating to endothelial cells some there have been a number of cells termed EPCs despite being unable to differentiate into functional endothelial cells. However currently there remains a lack of consensus on phenotypic and functional definition of endothelial precursor cells. Intense research is being undertaken into elucidating a consensus on classification and identification of EPCs. This will allow a better understanding of the function of EPCs in both health and disease but may also path the way for use of EPC as a viable treatment modality.

\section{References}

1. Deanfield JE, Halcox JP, Rabelink TJ (2007) Endothelial function and dysfunction: testing and clinical relevance. Circulation 115: 1285-1295.

2. Widlansky ME, Gokce N, Keaney JF, Vita JA (2003) The clinical implications of endothelial dysfunction. J Am Coll Cardiol 42: 1149-1160.

3. Munzel T, Sinning C, Post F, Warnholtz A, Schulz E (2008) Pathophysiology, diagnosis and prognostic implications of endothelial dysfunction. Ann Med 40: 180-196.

4. Ross R (1999) Atherosclerosis- an inflammatory disease. N Engl J Med 340 115-126.

5. Buijs JOD, Musters M, Verrips T, Post JA, Braam B, et al. (2004) Mathematica modeling of vascular endothelial layer maintenance: the role of endothelial cell division, progenitor cell homing, and telomere shortening. Am J Physiol Heart Circ Physiol 287: H2651-H2658.

6. Walter DH, Rittig K, Bahlmann FH, Silver M, Isner JM, et al. (2002) Statin therapy accelerates reendothelialization: a novel effect involving mobilization and incorporation of bone marrow-derived endothelial progenitor cells. Circulation 105: 3017-3024.

7. Griese DP, Ehsan A, Melo LG, Kong D, Zhang L, et al. (2003) Isolation and transplantation of autologous circulating endothelial cells into denuded vessels and prosthetic grafts: implications for cell-based vascular therapy. Circulation 108: $2710-2715$

8. Fujiyama S, Amano K, Uehira K, Yoshida M, Nishiwaki $Y$, et al (2003) Bone marrow monocyte lineage cells adhere on injured endothelium in a monocyte chemoattractant protein-1-dependent manner and accelerate reendothelialization as endothelial progenitor cells. Circ Res 93: 980-989.

9. Bhattacharya V, McSweeney PA, Shi Q, Bruno B, Ishida A, et al. (2000) Enhanced endothelialization and microvessel formation in polyester grafts seeded with CD34(+) bone marrow cells. Blood 95: 581-585.

10. Gehling UM, Ergun S, Schumacher U, Pantel K, Otte M, et al. (2000) In vitro differentiation of endothelial cells from AC133-positive progenitor cells. Blood 95: 3106-12.

11. Hu Y, Davison F, Zhang Z, Xu Q (2003) Endothelial replacement and angiogenesis in arteriosclerotic lesions of allografts are contributed by circulating progenitor cells. Circulation 108: 3122-3127.

12. Hill JM, Zalos G, Halcox JP, Finkel T, Schenke WH, et al. (2003) Circulating endothelial progenitor cells, vascular function, and cardiovascular risk. $\mathrm{N}$ Engl J Med 348: 593-600

13. Takahashi T, Kalka C, Masuda H, Chen D, Silver M, et al. (1999) Ischemia- and cytokine-induced mobilization of bone marrow-derived endothelial progenitor cells for neovascularization. Nat Med 5: 434-8.

14. Carmeliet P (2003) Angiogenesis in health and disease. Nat Med 9: 653-660.

15. Urbich C, Heeschen C, Aicher A, Dernbach E, Zeiher A, et al. (2003) Relevance of monocytic features for neovascularization capacity of circulating endothelial progenitor cells. Circulation 108: 2511-2516.

16. Nissen SE, Nicholls SJ, Sipahi I, Grasso AW, Hu T, et al. (2007) Effect of very high-intensity statin therapy on regression of coronary atherosclerosis: the Asteroid trial. JAMA 295: 1556-65.

17. Rafii S, Lyden D (2003) Therapeutic stem and progenitor cell transplantation for organ vascularization and regeneration. Nat Med 9: 702-712. 
Citation: Sandhu K, Njoroge W, Yang Y, Harper AGS, Butler R (2018) Endothelial Progenitor Cell Identification, Classification and Nomenclature: A Review. J Blood Lymph 8: 221. doi:10.4172/2165-7831.1000221

18. Mukai N, Akahori T, Komaki M, Ishii-Watabe A, Li Q, et al. (2008) A comparison of the tube forming potentials of early and late endothelial progenitor cells. Exp Cell Res 314: 430-440.

19. Deanfield J, Donald A, Ferri C, Giannattasio C, Halcox J, et al. (2005) Endothelial function and dysfunction. Part I: Methodological issues for assessment in the different vascular beds: a statement by the Working Group on Endothelin and Endothelial Factors of the European Society of Hypertension. J Hypertens 23: 7-17.

20. Dong C, Goldschmidt-Clermont PJ (2007) Endothelial progenitor cells: a promising therapeutic alternative for cardiovascular disease. J Interv Cardio 20: 93-99.

21. Asahara T, Murohara T, Sullivan A, Silver M, Li T, et al. (1997) Isolation of putative progenitor endothelial cells for angiogenesis. Science 275: 964-967.

22. Yoder MC (2012) Human endothelial progenitor cells. Cold Spring Harb Perspect Med 2: a006692.

23. Ingram DA, Caplice NM, Yoder MC (2005) Unresolved questions, changing definitions, and novel paradigms for defining endothelial progenitor cells. Blood 106: $1525-1531$

24. Shi Q, Rafii S, Wu MH, Yu C, Moore MA, et al. (1998) Evidence for circulating bone marrow-derived endothelial cells. Blood 92: 362-367.

25. Lin Y, Weisdorf DJ, Solovey A, Hebbel RP (2000) Origins of circulating endothelial cells and endothelial outgrowth from blood. J Clin Invest 105: 71-77.

26. Peichev M, Naiyer AJ, Pereira D, Zhu Z, Lane W, et al. (2000) Expression of VEGFR-2 and AC133 by circulating human CD34(+) cells identifies a population of functional endothelial precursors. Blood 95: 952-958.

27. Hirschi KK, Ingram DA, Yoder MC (2000) Assessing identity, phenotype, and fate of endothelial progenitor cells. Arterioscler Thromb Vasc Biol 28: 1584 1595.

28. Fadini GP, Losordo D, Dimmeler S (2012) Critical reevaluation of endothelia progenitor cell phenotypes for therapeutic and diagnostic use. Circ Res 110: 624-37.

29. Medina RJ, Barber CL, Sabatier F, Melero-Martin JM, Khosrotehrani K, et al. (2017) Endothelial Progenitors: A Consensus Statement on Nomenclature. Stem Cells Transl Med 6: 1316-1320.

30. Basile DP, Yoder MC (2014) Circulating and tissue resident endothelial progenitor cells. J Cell Physiol 229: 10-16.

31. Pearson JD (2010) Endothelial progenitor cells-an evolving story. Microvasc Res 79:162-168.

32. Sandhu K, Mamas M, Butler R (2017) Endothelial progenitor cells: Exploring the pleiotropic effects of statins. World J Cardiol 9: 1-13.

33. Yoon CH, Hur J, Park KW, Kim JH, Lee CS, et al. (2005) Synergistic neovascularization by mixed transplantation of early endothelial progenito cells and late outgrowth endothelial cells: the role of angiogenic cytokines and matrix metalloproteinases. Circulation 112: 1618-1627.

34. Murasawa S, Asahara T (2005) Endothelial progenitor cells for vasculogenesis. Physiology (Bethesda) 20: 36-42.

35. Barber CL, Iruela-Arispe ML (2006) The ever-elusive endothelial progenitor cell: identities, functions and clinical implications. Pediatr Res 59: 26R-32R.

36. Padfield GJ, Newby DE, Mills NL (2010) Understanding the role of endothelia progenitor cells in percutaneous coronary intervention. J Am Coll Cardiol 55 1553-1565.

37. Schachinger V, Britten MB, Zeiher AM (2000) Prognostic impact of coronary vasodilator dysfunction on adverse long-term outcome of coronary heart disease. Circulation 101: 1899-1906.

38. Suwaidi JA, Hamasaki S, Higano ST, Nishimura RA, Holmes DR Jr, et al. (2000) Long-term follow-up of patients with mild coronary artery disease and endothelial dysfunction. Circulation 101: 948-954.

39. Halcox JP, Schenke WH, Zalos G, Mincemoyer R, Prasad A, et al. (2002) Prognostic value of coronary vascular endothelial dysfunction. Circulation 106 653-658.

40. Gokce N, Keaney JF, Jr Hunter LM, Hunter LM, Watkins MT, et al. (2002) Risk stratification for postoperative cardiovascular events via noninvasive assessment of endothelial function: a prospective study. Circulation 105: 1567-1572.
41. Pirro M, Schillaci G, Menecali C, Bagaglia F, Paltriccia R, et al. (2007) Reduced number of circulating endothelial progenitors and HOXA9 expression in CD34+ cells of hypertensive patients. J Hypertens 25: 2093-2099.

42. Fadini GP, Miorin M, Facco M, Bonamico S, Baesso I, et al. (2005) Circulating endothelial progenitor cells are reduced in peripheral vascular complications of type 2 diabetes mellitus. J Am Coll Cardiol 45: 1449-1457.

43. Tepper OM, Galiano RD, Capla JM, Kalka C, Gagne PJ, et al. (2002) Human endothelial progenitor cells from type II diabetics exhibit impaired proliferation, adhesion, and incorporation into vascular structures. Circulation 106: 2781 2786

44. li M, Takenaka H, Asai J, Ibusuki K, Mizukami Y, et al. (2006) Endothelia progenitor thrombospondin-1 mediates diabetes-induced delay in reendothelialization following arterial injury. Circ Res 98: 697-704.

45. Chen YH, Lin SJ, Lin FY, Wu TC, Tsao CR, et al. (2007) High glucose impairs early and late endothelial progenitor cells by modifying nitric oxide-related but not oxidative stress-mediated mechanisms. Diabetes 56: 1559-1568.

46. Imanishi T, Hano T, Nishio I (2004) Angiotensin II potentiates vascular endothelial growth factor-induced proliferation and network formation of endothelial progenitor cells. Hypertens Res 27: 101-108.

47. Min TQ, Zhu CJ, Xiang WX, Hui ZJ, Peng SY (2004) Improvement in endothelia progenitor cells from peripheral blood by ramipril therapy in patients with stable coronary artery disease. Cardiovasc Drugs Ther 18: 203-209.

48. Vasa M, Fichtlscherer S, Aicher A, Adler K, Urbich C, et al. (2001) Number and migratory activity of circulating endothelial progenitor cells inversely correlate with risk factors for coronary artery disease. Circ Res 89: E1-7.

49. Chen JZ, Zhang FR, Tao QM, Wang XX, Zhu JH, et al. (2004) Number and activity of endothelial progenitor cells from peripheral blood in patients with hypercholesterolaemia. Clin Sci (Lond) 107: 273-280.

50. Ito H, Rovira II, Bloom ML, Takeda K, Ferrans VJ, et al. (1999) Endothelial progenitor cells as putative targets for angiostatin. Cancer Res 59: 5875-5877.

51. Li D, Yang B, Mehta JL (1998) Ox-LDL induces apoptosis in human coronary artery endothelial cells: role of PKC, PTK, bcl-2, and Fas. Am J Physiol 275 H568-576.

52. Chavakis E, Dernbach E, Hermann C, Mondorf UF, Zeiher AM, et al. (2001) Oxidized LDL inhibits vascular endothelial growth factor-induced endothelia cell migration by an inhibitory effect on the Akt/endothelial nitric oxide synthase pathway. Circulation 103: 2102-2107.

53. Morales-Ruiz, M, Fulton D, Sowa G, Languino LR, Fujio Y, et al. (2000) Vascular endothelial growth factor-stimulated actin reorganization and migration of endothelial cells is regulated via the serine/threonine kinase Akt. Circ Res 86: 892-896.

54. Rouhl RP, van Oostenbrugge RJ, Damoiseaux J, Tervaert JW, Lodder (2008) Endothelial progenitor cell research in stroke: a potential shift in pathophysiological and therapeutical concepts. Stroke 39: 2158-2165.

55. Sen S, McDonald SP, Coates PT, Bonder CS (2011) Endothelial progenitor cells: novel biomarker and promising cell therapy for cardiovascular disease. Clin Sci (Lond) 120: 263-283.

56. Dimmeler S, Vasa-Nicotera M (2003) Aging of progenitor cells: limitation for regenerative capacity? J Am Coll Cardiol 42: 2081-2082.

57. Flores-Ramirez R, Uribe-Longoria A, Rangel-Fuentes MM, Gutiérrez-Fajardo P, Salazar-Riojas R, et al. (2010) Intracoronary infusion of CD133+ endothelia progenitor cells improves heart function and quality of life in patients with chronic post-infarct heart insufficiency. Cardiovasc Revasc Med 11: 72-78.

58. Dobert N, Britten M, Assmus B, Berner U, Menzel C, et al. (2004) Transplantation of progenitor cells after reperfused acute myocardial infarction: evaluation of perfusion and myocardial viability with FDG-PET and thallium SPECT. Eur J Nucl Med Mol Imaging 31: 1146-51.

59. Assmus B, Honold J, Schachinger V, Britten MB, Fischer-Rasokat U, et al. (2006) Transcoronary transplantation of progenitor cells after myocardial infarction. N Engl J Med 355: 1222-1232.

60. Losordo DW, Schatz RA, White CJ, Udelson JE, Veereshwarayya V, et al. (2007) Intramyocardial transplantation of autologous CD34+ stem cells for intractable angina: a phase $1 / /$ la double-blind, randomized controlled trial. Circulation 115: 3165-3172

61. Bartunek J, Vanderheyden M, Vandekerckhove B, Mansour S, De Bruyne B, 
Citation: Sandhu K, Njoroge W, Yang Y, Harper AGS, Butler R (2018) Endothelial Progenitor Cell Identification, Classification and Nomenclature: A Review. J Blood Lymph 8: 221. doi:10.4172/2165-7831.1000221

et al. (2005) Intracoronary injection of CD133-positive enriched bone marrow progenitor cells promotes cardiac recovery after recent myocardial infarction: feasibility and safety. Circulation 112: |178-1183.

62. Erbs S, Linke A, Adams V, Lenk K, Thiele H, et al. (2005) Transplantation of blood-derived progenitor cells after recanalization of chronic coronary artery occlusion: first randomized and placebo-controlled study. Circ Res 97: 756762.

63. Hamano K, Nishida M, Hirata K, Mikamo A, Li TS, et al. (2001) Loca implantation of autologous bone marrow cells for therapeutic angiogenesis in patients with ischemic heart disease: clinical trial and preliminary results. Jpn Circ J 65: 845-847

64. Strauer BE, Brehm M, Zeus T, Köstering M, Hernandez A, et al. (2002) Repair of infarcted myocardium by autologous intracoronary mononuclear bone marrow cell transplantation in humans. Circulation 106: 1913-1918.

65. Meyer GP, Wollert KC, Lotz J, Steffens J, Lippolt P, et al. (2006) Intracoronary bone marrow cell transfer after myocardial infarction: eighteen months' followup data from the randomized, controlled BOOST (Bone marrow transfer to enhance ST-elevation infarct regeneration) trial. Circulation 113: 1287-1294.

66. Janssens S, Dubois C, Bogaert J, Theunissen K, Deroose C, et al. (2006) Autologous bone marrow-derived stem-cell transfer in patients with STsegment elevation myocardial infarction: double-blind, randomised controlled trial. Lancet 367: 113-121.

67. Schachinger V, Erbs S, Elsasser A, Haberbosch W, Hambrecht R, et al. (2006) Improved clinical outcome after intracoronary administration of bone-marrowderived progenitor cells in acute myocardial infarction: final 1-year results of the REPAIR-AMI trial. Eur Heart J 27: 2775-2783.

68. Medina RJ, O'Neill CL, O'Doherty TM, Stitt AW, Willson SE (2012) Endothelial progenitors as tools to study vascular disease. Stem Cells Int 2012: 346735.

69. Yin AH, Miraglia S, Zanjani ED, Ogawa M, Leary AG, et al. (1997) AC133, a novel marker for human hematopoietic stem and progenitor cells. Blood 90 5002-5012.

70. Quirici N, Soligo D, Caneva L, Servida F, Bossolasco P, et al. (2011) Differentiation and expansion of endothelial cells from human bone marrow CD133(+) cells. Br J Haematol 115: 186-94.

71. Timmermans, F, Van Hauwermeiren F, De Smedt M, Plasschaert, F, De Buyzere ML et al. (2007) Endothelial outgrowth cells are not derived from CD133+ cells or CD45+ hematopoietic precursors. Arterioscler Thromb Vasc Biol 27: 1572-1579.

72. Case J, Mead LE, Bessler WK, Prater D, White HA, et al. (2007) Human CD34+AC133+VEGFR-2+ cells are not endothelial progenitor cells but distinct, primitive hematopoietic progenitors. Exp Hematol 35: 1109-1118.

73. Gill M, Dias S, Hattori K, Rivera ML, Hicklin D, et al. (2001) Vascular trauma induces rapid but transient mobilization of VEGFR2(+)AC133(+) endothelial precursor cells. Circ Res 88: 167-174.

74. Bertolini F, Shaked Y, Mancuso P, Kerbel RS (2006) The multifaceted circulating endothelial cell in cancer: towards marker and target identification. Nat Rev Cancer. 6: 835-845.

75. Madeddu P, Emanueli C, Pelosi E, Salis MB, Cerio A, et al. (2004) Transplantation of low dose CD34+KDR+ cells promotes vascular and muscular regeneration in ischemic limbs. FASEB J 18: 1737-1739.

76. Schmidt-Lucke C, Fichtlscherer S, Aicher A, Schultheiss HP, Zeiher AM, et al. (2010) Quantification of circulating endothelial progenitor cells using the modified ISHAGE protocol. PLoS One 5: e13790.

77. Farace F, Gross-Goupil M, Tournay E, Taylor M, Vimond N, et al. (2011) Levels of circulating CD45(dim)CD34(+)VEGFR2(+) progenitor cells correlate with outcome in metastatic renal cell carcinoma patients treated with tyrosine kinase inhibitors. Br J Cancer 104: 1144-1150.

78. Fadini GP, Baesso I, Albiero M, Sartore S, Agostini C, et al. (2008) Technical notes on endothelial progenitor cells: ways to escape from the knowledge plateau. Atherosclerosis 197: 496-503.

79. Hristov M, Erl W, Weber PC (2003) Endothelial progenitor cells: mobilization, differentiation, and homing. Arterioscler Thromb Vasc Biol 23: 1185-1189.

80. Urbich, C, Dimmeler S (2008) Endothelial progenitor cells: characterization and role in vascular biology. Circ Res 95: 343-353.

81. Asahara T, Masuda H, Takahashi T, Kalka, C, Pastore C, et al. (1999)
Bone marrow origin of endothelial progenitor cells responsible for postnatal vasculogenesis in physiological and pathological neovascularization. Circ Res 85: 221-228.

82. Wu X, Lensch MW, Wylie-Sears J, Bischoff J (2007) Hemogenic endothelia progenitor cells isolated from human umbilical cord blood. Stem Cells 25: 2770 2776

83. Kaushal S, Amiel GE, Guleserian KJ (2008) Functional small-diameter neovessels created using endothelial progenitor cells expanded ex vivo. Nat Med 7: 1035-1040.

84. Brown M, Wittwer C (2000) Flow cytometry: principles and clinical applications in hematology. Clin Chem 46: 1221-1229.

85. Prokopi M, Pula G, Mayr U (2009) Proteomic analysis reveals presence of platelet microparticles in endothelial progenitor cell cultures. Blood 114: 723-732.

86. Kim SJ, Kim JS, Papadopoulos J (2009) Circulating monocytes expressing CD31: implications for acute and chronic angiogenesis. Am J Pathol 174: 1972 1980.

87. Yoder MC, Mead LE, Prater D (2007) Redefining endothelial progenitor cells via clonal analysis and hematopoietic stem/progenitor cell principals. Blood 109: $1801-1809$

88. Sieveking DP, Buckle A, Celermajer DS (2008) Strikingly different angiogenic properties of endothelial progenitor cell subpopulations: insights from a nove human angiogenesis assay. J Am Coll Cardiol 51: 660-668.

89. Werner N, Kosiol S, Schiegl T (2005) Circulating endothelial progenitor cells and cardiovascular outcomes. N Engl J Med 353: 999-1007.

90. Zhao J, Mitrofan CG, Appleby SL Disrupted Endothelial Cell Layer and Exposed Extracellular Matrix Proteins Promote Capture of Late Outgrowth Endothelial Progenitor Cells. Stem Cells Int 2016: 1406304.

91. Matsumura, M, Fukuda, N, Kobayashi N (2009) Effects of atorvastatin on angiogenesis in hindlimb ischemia and endothelial progenitor cell formation in rats. J Atheroscler Thromb 16: 319-326.

92. Asahara T, Kawamoto A, Masuda $H$ (2011) Concise review: Circulating endothelial progenitor cells for vascular medicine. Stem Cells 29: 1650-1655.

93. Rehman, J, Li J, Orschell CM (2003) Peripheral blood "endothelial progenitor cells" are derived from monocyte/macrophages and secrete angiogenic growth factors. Circulation 107: 1164-1169.

94. Zhang SJ, Zhang H, Wei YJ (2006) Adult endothelial progenitor cells from human peripheral blood maintain monocyte/macrophage function throughout in vitro culture. Cell Res16: 577-584.

95. Asakage M, Tsuno NH, Kitayama J (2006) Early-outgrowth of endothelia progenitor cells can function as antigen-presenting cells. Cancer Immunol Immunother 55: 708-16.

96. Vaughan EE, O’Brien T (2012) Isolation of circulating angiogenic cells. Methods Mol Biol 916: 351-356.

97. O'Neill CL, Guduric-Fuchs J, Chambers SE, et al. (2016) Endothelial cellderived pentraxin 3 limits the vasoreparative therapeutic potential of circulating angiogenic cells. Cardiovasc Res112(3): p. 677-688

98. Stitt AW, O'Neill CL, O'Doherty MT (2011) Vascular stem cells and ischaemic retinopathies. Prog Retin Eye Res 30: 149-166.

99. Chambers SE, O'Neill CL, O'Doherty TM (2016) The role of immune-related myeloid cells in angiogenesis. Immunobiology 218: 1370-1375.

100. Kanayasu-Toyoda T, Tanaka T, Kikuchi Y (2016) Cell-Surface MMP-9 Protein Is a Novel Functional Marker to Identify and Separate Proangiogenic Cells from Early Endothelial Progenitor Cells Derived from CD133(+) Cells. Stem Cells 34: 1251-1262.

101. Urbich C, Aicher A, Heeschen C (2005) Soluble factors released by endothelia progenitor cells promote migration of endothelial cells and cardiac resident progenitor cells. J Mol Cell Cardiol, 39: 733-742.

102. Medina RJ, O'Neill CL, O'Doherty TM (2011) Myeloid angiogenic cells act as alternative M2 macrophages and modulate angiogenesis through interleukin-8. Mol Med 17: 1045-1055.

103. Ingram DA, Mead LE, Tanaka H (2004) Identification of a novel hierarchy of endothelial progenitor cells using human peripheral and umbilical cord blood. Blood 104: 2752-2760. 
Citation: Sandhu K, Njoroge W, Yang Y, Harper AGS, Butler R (2018) Endothelial Progenitor Cell Identification, Classification and Nomenclature: A Review. J Blood Lymph 8: 221. doi:10.4172/2165-7831.1000221

104.Zhao J, Bolton EM, Randle L (2014) Functional characterization of late outgrowth endothelial progenitor cells in patients with end-stage renal failure. Transpl Int 27: 437-451.

105. Tasev D, Koolwijk P, van Hinsbergh VW (2016) Therapeutic Potential of Human-Derived Endothelial Colony-Forming Cells in Animal Models. Tissue Eng Part B Rev 22: 371-382.

106. Lin RZ, Moreno-Luna R, Li D (2014) Human endothelial colony-forming cells serve as trophic mediators for mesenchymal stem cell engraftment via paracrine signaling. Proc Natl Acad Sci USA 111: 10137-10142.

107.Stroncek JD, Grant BS, Brown MA (2009) Comparison of endothelial cell phenotypic markers of late-outgrowth endothelial progenitor cells isolated from patients with coronary artery disease and healthy volunteers. Tissue Eng Part A 15: 3473-3486.

108. Medina RJ, O'Neil CL, O'Doherty TM (2013) Ex vivo expansion of human outgrowth endothelial cells leads to IL-8-mediated replicative senescence and impaired vasoreparative function. Stem Cells 31: 1657-1668.

109. Patel J, Wong HY, Wang W (2016) Self-Renewal and High Proliferative Colony Forming Capacity of Late-Outgrowth Endothelial Progenitors Is Regulated by
Cyclin-Dependent Kinase Inhibitors Driven by Notch Signaling. Stem Cells 34 902-912

110. Yamamoto K, Takahashi T, Asahara T (2003) Proliferation, differentiation, and tube formation by endothelial progenitor cells in response to shear stress. J Appl Physiol 95: 2081-2088.

111. Obi S, Yamamoto K, Shimizu N (2009) Fluid shear stress induces arterial differentiation of endothelial progenitor cells. J Appl Physiol 106: 203-211.

112. Mazzolai L, Bouzourene K, Hayoz D (2011) Characterization of human late outgrowth endothelial progenitor-derived cells under various flow conditions. J Vasc Res 48: 443-451.

113. Brown MA, Wallace CS, Angelos M (2009) Characterization of umbilical cord blood-derived late outgrowth endothelial progenitor cells exposed to laminar shear stress. Tissue Eng Part A, 15: 3575-3587.

114. Prater DN, Case J, Ingram DA (2007) Working hypothesis to redefine endothelial progenitor cells. Leukemia 21:1141-1149.

115. Prasain N, Meador JL, Yoder MC (2012) Phenotypic and functional characterization of endothelial colony forming cells derived from human umbilical cord blood. J Vis Exp 2012. 